\title{
ASSOCIATION OF MTHFR A1298C GENE VARIANT, DNA DAMAGE, AND TOTAL ANTIOXIDANT STATUS WITH THE RISK OF TYPE 2 DIABETES MELLITUS AND ITS COMPLICATIONS
}

\author{
NITHYA K ${ }^{1 *}$, ISABEL $\mathbf{W}^{1}$, ANGELINE $\mathrm{T}^{2}$, PRISCILLA AS ${ }^{1}$, ASIRVATHAM AJ ${ }^{3}$ \\ ${ }^{1}$ Department of Zoology, Lady Doak College, Madurai, Tamil Nadu, India. ${ }^{2}$ Department of Zoology, The American College, Madurai, Tamil \\ Nadu, India. ${ }^{3}$ Department of Diabetology, Arthur Asirvatham Hospital, Madurai, Tamil Nadu, India. Email: nithyadeiva@gmail.com
}

Received: 01 February 2018, Revised and Accepted: 21 March 2018

\section{ABSTRACT}

Objectives: We have examined the association of methylenetetrahydrofolate reductase (MTHFR) gene A1298C variant, DNA damage, and total antioxidant status (TAS) in patients with type 2 diabetes mellitus (T2DM) with and without complications and in healthy controls.

Methods: A total of 300 subjects including 100 patients with complications, 100 patients without complications, and 100 controls were included. TAS was assessed by ferric reducing ability of plasma assay. DNA damage was analyzed in lymphocytes using the comet assay. Polymerase chain reactionrestriction fragment length polymorphism analysis was performed to study the MTHFR A1298C gene polymorphism among the study subjects.

Results: The results revealed that the MTHFR 1298 AC+CC genotypes were associated with increased risk (2 fold) for diabetes and its complications. When the effect of DNA damage was analyzed, significant differences between individuals with mutant and normal genotype among the diabetic patients (with and without complications) was observed ( $p \leq 0.001$ ). In contrary, no significant difference was found between TAS and 1298 genotypes (AA versus $\mathrm{AC}+\mathrm{CC}$ ) in type 2 diabetic patients (with and without complications), $\mathrm{p}=0.338$. We also found a significant difference between the genotypes of the MTHFR A1298C and DNA damage, TAS in T2DM patients (with and without complications) when compared to controls, $\mathrm{p}<0.001$.

Conclusions: Our findings suggest that the MTHFR A1298C gene polymorphism is considered as a risk factor for the development of diabetes and its complications among south Indians. Therefore, increased DNA damage and decreased TAS along with the occurrence of a mutant genotype in an individual with diabetes may be at an increased risk for the development of chronic complications.

Keywords: Methylenetetrahydrofolate reductase, Polymorphism, Folate metabolism, Total antioxidant status, DNA damage, Type 2 diabetes mellitus.

(C) 2018 The Authors. Published by Innovare Academic Sciences Pvt Ltd. This is an open access article under the CC BY license (http://creativecommons. org/licenses/by/4. 0/) DOI: http://dx.doi.org/10.22159/ajpcr.2018.v11i6.25076

\section{INTRODUCTION}

The incidence of type 2 diabetes mellitus (T2DM) is rising at an alarming rate, and the prevalence of this disease has led to different vascular complications [1,2]. Vascular complications may be macrovascular (coronary heart disease, peripheral vascular disease, and stroke), microvascular (neuropathy, retinopathy, and nephropathy), and both micro- and macro-vascular (diabetic foot) [3]. T2DM is a common multifactorial genetic syndrome, which is determined by several different genes and environmental factors [4].

Functional polymorphism in genes involved in the folate metabolic pathway has been associated with low level of folate and a high level of homocysteine (Hcy) [5-7]. Methylenetetrahydrofolate reductase (MTHFR) is the key enzyme that plays an important role in folate metabolism. The MTHFR enzyme, encoded by the MTHFR gene, is responsible for catalyzing the irreversible reaction of 5 , 10 -methylenetetrahydrofolate to 5-methyltetrahydrofolate which is the primary circulating form of folate [8]. The gene encoding MTHFR is located at chromosome 1p36.3. Single-nucleotide polymorphism (SNP) in MTHFR A1298C (rs1801131) leads to glutamate to alanine substitution within the C-terminal regulatory domain of the enzyme due to an $\mathrm{A}$ to $\mathrm{C}$ transversion that occurs in exon 7 , that results in a decrease in MTHFR activity [9]. Low MTHFR activity reduces DNA methylation [10], thereby results in elevated plasma homocysteine (Hcy) [11]. Several studies have also shown that elevated levels of Hcy may induce DNA damage either by an increased production of ROS or by biological mechanisms directly associated with an excessive misincorporation of uracil in DNA and the process of DNA methylation [12-14].
To date, over 40 genetic mutations in MTHFR gene have been identified, of which A1298C and C677T showed the most clinical significance. Few studies have evaluated the relationship between the MTHFR A1298C polymorphism and susceptibility of diabetes, and the results remain inclusive [15]. Hence, the present study was designed to find the association of MTHFR gene A1298C polymorphism with the risk of type 2 diabetes and also to find out the effect of this polymorphism on DNA damage and total antioxidant status (TAS) in type 2 diabetic patients and healthy controls among south Indians.

\section{METHODS}

\section{Study subjects}

Two hundred type 2 diabetic patients $(\mathrm{n}=100$, with complications \& $\mathrm{n}=100$, without complications) and 100 healthy individuals who were of south Indian Tamil ethnicity were included in the study. Complications included in the study were coronary heart disease (18\%), peripheral vascular disease $(16 \%)$, stroke (1\%), neuropathy (56\%), retinopathy $(1 \%)$, nephropathy $(6 \%)$, and foot ulcer $(2 \%)$. The ethical clearance was obtained from the Institutional Ethical Committee of Asirvatham Hospital and the study was approved by the Institutional Biosafety Committee of Lady Doak College. Samples were collected with the informed consent from all the study subjects.

Ferric reducing ability of plasma (FRAP) assay

Total antioxidant status was measured by FRAP assay according to the method of Benzie and Strain [16]

Single-cell gel electrophoresis (comet assay)

Comet assay was performed to assess the level of DNA damage in peripheral lymphocytes by two-layer method according to Tice et al., 2000 [17] with slight modifications according to Singh et al., 1988 [18]. 
Genotyping of MTHFR A1298C gene

Genomic DNA was extracted from the whole blood $(500 \mu \mathrm{l})$ by phenol-chloroform method [19]. The genotyping was performed by polymerase chain reaction-restriction fragment length polymorphism (PCR-RFLP) analysis according to Friedman et al., 1999 [20]. PCR amplification was carried out using the following primer set: forward primer 5' CTTTGGGGAGCTGAAGGACTACTAC 3' and reverse primer 5' CACTTTGTGACCATTCCGGTTTG 3' ( 10picomoles) (Sigma). The amplified PCR product (163bp) was confirmed by $2 \%$ agarose (HiMedia, Mumbai) gel electrophoresis (Fig. 1), using the Gel documentation system. The amplified products were digested with MboII enzyme (Fermentas Life Sciences, Germany) at $37^{\circ} \mathrm{C}$ for $5-7 \mathrm{~h}$. The resulting fragments of the digested PCR products were 84, 31, 30, and $18 \mathrm{bp}$ fragments for the A allele and 56, 31, 30, 28, and $18 \mathrm{bp}$ fragments for the $\mathrm{C}$ allele (Fig. 2). The products were visualized by performing agarose (3\%) gel electrophoresis using a UV transilluminator

\section{Sequencing of PCR amplified fragments}

Selected PCR amplified fragments were completely sequenced both strands in an automated ABI 3100 Genetic Analyzer (Chromous biotech, Bengaluru, India). Sequencing and BLASTN analysis were done to confirm whether the amplified fragment was the MTHFR A1298C gene sequence.

\section{Statistical analysis}

All the data were expressed as mean \pm standard error. Genotype and allele frequencies were calculated by the allele counting method. The Hardy-Weinberg equilibrium was calculated for diabetic patients and controls and was tested using the Chi-square $\left(\chi^{2}\right)$ statistics. Odds ratio (OR) and 95\% confidence intervals (95\% CI) were calculated. Statistical analysis was performed using the Sigma stat 11.0 version software, and $\mathrm{p} \leq 0.05$ was considered to be statistically significant.

\section{RESULTS}

When BLASTN analysis was performed, 100\% high degree of identity was found between the MTHFR A1298C gene and the submitted DNA sequences. The genotype and allele frequencies of MTHFR A1298C gene polymorphism and Hardy-Weinberg equilibrium in type 2 diabetic patients (with and without complications) and controls are shown in Table 1. Among the 200 T2DM patients, $59.5 \%$ of the individuals have $\mathrm{AC}$ genotype and $22 \%$ of the individuals have CC genotype and the remaining $18.5 \%$ of the individuals have AA genotype. The calculated genotype frequencies were slightly higher in T2DM patients when compared to controls ( $40 \% \mathrm{AC}, 39 \% \mathrm{AA}$ and $21 \%$ CC genotype). The most prevalent genotype for MTHFR A1298C gene was heterozygous (AC) in both patients with and without complications and controls. The $\mathrm{C}$ allele frequency was found to be slightly higher in patients with complications (0.53) than patients without complications (0.51) when compared to controls $(0.41)$. The genotype distributions in T2DM patients (without complications) have shown a marked deviation from the frequencies predicted on the basis of the Hardy-Weinberg law $\left(\chi^{2}=4.84, p=0.02\right)$ and equilibrium was observed in both the patients with complications $\left(\chi^{2}=2.69, \mathrm{p}=0.10\right)$ and the control group $\left(\chi^{2}=2.99\right.$, $\mathrm{p}=0.22$ ) for MTHFR A1298C polymorphism.

Significant differences were found when type 2 diabetic patients (with and without complications) and controls were compared according to AA genotype versus $\mathrm{AC}+\mathrm{CC}$ genotypes of the MTHFR A1298C gene (patients with complications: $p=0.001, O R=2.91,95 \%$ $\mathrm{CI}=1.52-5.57$ \& patients without complications: $\mathrm{p}=0.002$, $\mathrm{OR}=2.72$, $95 \% \mathrm{CI}=1.43-5.17)$. The results revealed that the MTHFR A1298C gene polymorphism is associated with increased risk ( 2 fold) for diabetes and its complications.

We studied the effect of MTHFR A1298C on TAS and DNA damage in type 2 diabetic patients (with and without complications) and controls (Table 2). When the effect of DNA damage was analyzed, significant differences between individuals with mutant and normal genotype among the diabetic patients (with and without complications) was

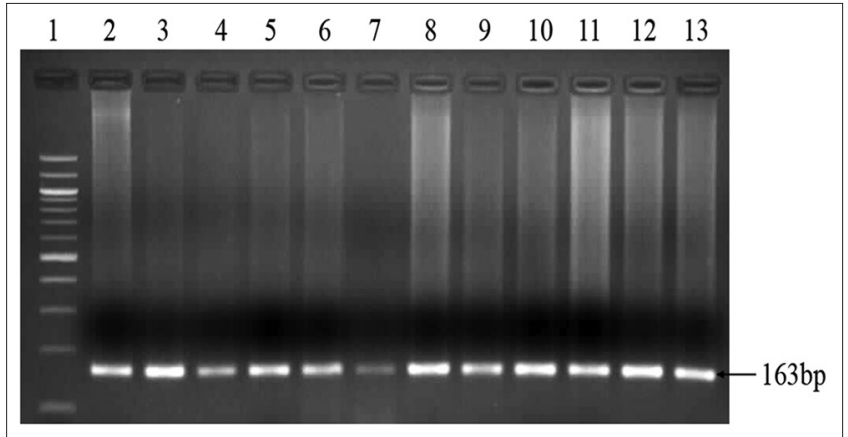

Fig. 1: Polymerase chain reaction (PCR) analysis of the MTHFR A1298C gene. Lane 1: 100 bp DNA marker, Lane 2-13: PCR product (163 bp)

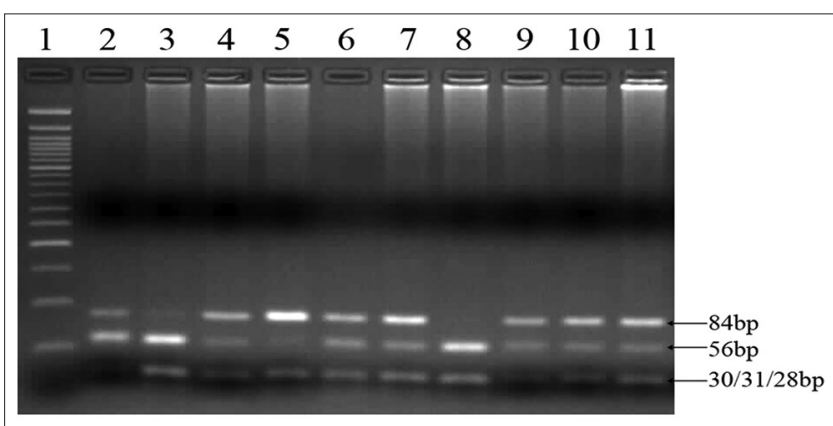

Fig. 2: Restriction digestion analysis of the MTHFR A1298C gene variant. Lane 1: 100 bp DNA marker, Lane 5: wild genotype

(AA)- 84, 31, 30 and 18 bp, Lane 2, 4, 6, 7, 9-11: heterozygous genotype (AC)- 84, 56, 31, 30, 28 and $18 \mathrm{bp}$, Lane 3 and 8 : mutant genotype (CC)- 56, 31, 30, 28 and 18 bp

observed ( $\mathrm{p} \leq 0.001)$. In contrary, no significant difference was found between TAS and 1298 genotypes (AA vs. AC+CC) in type 2 diabetic patients (with and without complications), $\mathrm{p}=0.338$. We also found a significant difference between the genotypes of the MTHFR A1298C and DNA damage, TAS in T2DM patients (with \& without complications) when compared to controls, $\mathrm{p}<0.001$.

The association between the MTHFR genotypes versus age, duration, sugar level, and HbA1c in patients with and without complications is shown in Table 3. We did not observe any significant association between the wild genotype (AA) and mutant genotypes $(\mathrm{A} / \mathrm{C} \& \mathrm{C} / \mathrm{C})$ in both diabetic patients (with and without complications) with regard to their age, duration, sugar level, and HbA1c level ( $p>0.05)$.

\section{DISCUSSION}

Diabetes is a serious illness resulting in chronic complications and growing threat to the health of the global world. It has been suggested that the chronic complications could be prevented by initial understanding of the disease and through better diabetes mellitus treatment [21]. Another finding suggests that the level of glycemic control and the presence of complications are associated with quality of life [22]. In the present study, the association of MTHFR gene (A1298C) variant, DNA damage and TAS with the risk of type 2 diabetes and its complications were analyzed among south Indians.

\section{MTHFR A1298C gene polymorphism and T2DM}

The MTHFR 1298C allele frequency observed in the present study was found to be 0.53 for patients with complications and 0.51 for patients without complications. Our findings revealed that the MTHFR A1298C polymorphism is more prevalent in South Indian population and associated with the risk of diabetes and its complications. Moreover, statistical comparison between type 2 diabetic patients and controls 
Table 1: MTHFR A1298C gene polymorphism - Genotype and Allele Frequency in type 2 diabetic patients (with and without vascular complications) and controls

\begin{tabular}{|c|c|c|c|c|}
\hline Genotype/Allele & Patients with complications $(n=100)$ & \multicolumn{2}{|c|}{ Patients without complications $(n=100)$} & Controls $(n=100)$ \\
\hline \multicolumn{5}{|l|}{ Genotypes } \\
\hline $\mathrm{AA}$ & 18 & 19 & & 39 \\
\hline $\mathrm{AC}$ & 58 & 61 & & 40 \\
\hline $\mathrm{CC}$ & 24 & 20 & & 21 \\
\hline \multicolumn{5}{|l|}{ Alleles } \\
\hline A & 0.47 & 0.49 & & 0.59 \\
\hline $\mathrm{C}$ & 0.53 & 0.51 & & 0.41 \\
\hline \multicolumn{2}{|l|}{ Cases versus controls } & Odds ratio & $95 \% \mathrm{CI}$ & p value \\
\hline \multicolumn{5}{|l|}{ AA versus $\mathrm{AC}+\mathrm{CC}$} \\
\hline \multirow{2}{*}{\multicolumn{2}{|c|}{$\begin{array}{l}\text { Patients without } \\
\text { complications versus } \\
\text { Controls }\end{array}$}} & 2.72 & $1.43-5.17$ & 0.002 \\
\hline & & & & \\
\hline \multicolumn{2}{|l|}{$\begin{array}{l}\text { Patients with } \\
\text { complications versus }\end{array}$} & 2.91 & $1.52-5.57$ & 0.001 \\
\hline
\end{tabular}

Controls

MTHFR: methylenetetrahydrofolatereductase, n: number of individuals, HWE: Hardy-Weinberg equilibrium, $\chi^{2:}$ Chi-square, CI: Confidence interval, *p<0.05 statistically significant

Table 2: Effect of MTHFR 1298 genotypes on TAS and DNA Damage in type 2 diabetic patients (with and without complications) and controls

\begin{tabular}{|c|c|c|c|c|c|c|}
\hline \multirow[t]{2}{*}{ Genotypes } & \multicolumn{3}{|c|}{ TAS $(\mu \mathrm{mol} / \mathrm{L})$ mean $\pm \mathrm{SE}$} & \multicolumn{3}{|c|}{ DNA damage $(\%)$ mean \pm SE } \\
\hline & $\begin{array}{l}\text { T2DM patients } \\
\text { with complications } \\
(n=100)\end{array}$ & $\begin{array}{l}\text { T2DM patients } \\
\text { without complications } \\
(n=100)\end{array}$ & $\begin{array}{l}\text { Controls } \\
(n=100)\end{array}$ & $\begin{array}{l}\text { T2DM patients } \\
\text { with complications } \\
(n=100)\end{array}$ & $\begin{array}{l}\text { T2DM patients } \\
\text { without complications } \\
(n=100)\end{array}$ & $\begin{array}{l}\text { Controls } \\
(n=100)\end{array}$ \\
\hline AA & $605.26 \pm 35.56(18)$ & $681.05 \pm 43.80(19)$ & $967.60 \pm 22.17$ (39) & $10.36 \pm 1.69(18)$ & $4.65 \pm 1.12(19)$ & $2.11 \pm 0.13(39)$ \\
\hline $\mathrm{AC}$ & $562.41 \pm 20.10(58)$ & $637.35 \pm 24.52(61)$ & $948.0 \pm 35.06(40)$ & $11.94 \pm 1.23(58)$ & $9.39 \pm 0.72(61)$ & $2.04 \pm 0.20(40)$ \\
\hline $\mathrm{CC}$ & $610.83 \pm 48.43(24)$ & $560.0 \pm 55.60(20)$ & $980.95 \pm 53.83(21)$ & $15.93 \pm 1.89(24)$ & $10.41 \pm 1.45(20)$ & $1.78 \pm 0.23(21)$ \\
\hline
\end{tabular}

Data are presented as mean \pm standard error, MTHFR: Methylenetetrahydrofolate reductase, T2DM: Type 2 diabetes mellitus, n: Number of individuals. SE: Standard error, TAS: Total antioxidant status

Table 3: Association between MTHFR A1298C gene polymorphism versus clinical and biochemical parameters in patients with and without complications

\begin{tabular}{|c|c|c|c|c|c|c|}
\hline \multirow[t]{2}{*}{ Parameters } & \multicolumn{2}{|c|}{ T2DM patients with complications } & \multirow[t]{2}{*}{$\mathbf{p}$} & \multicolumn{2}{|c|}{ T2DM patients without complications } & \multirow[t]{2}{*}{$\mathbf{p}$} \\
\hline & $\mathrm{A} / \mathrm{A}(n=18)$ & A/C \& C/C $(n=82)$ & & $\mathrm{A} / \mathrm{A}(n=19)$ & $\mathrm{A} / \mathrm{C} \& \mathrm{C} / \mathrm{C}(n=81)$ & \\
\hline Age (Yrs) & $56.61 \pm 1.45$ & $55.0 \pm 0.82$ & 0.421 & $46.05 \pm 2.43$ & $48.79 \pm 1.01$ & 0.239 \\
\hline Sugar Level (mmol/L) & $12.49 \pm 0.92$ & $12.81 \pm 0.43$ & 0.459 & $14.53 \pm 0.90$ & $12.22 \pm 0.39$ & 0.017 \\
\hline HbA1c $(\%)$ & $8.57 \pm 0.28$ & $8.76 \pm 0.19$ & 0.904 & $9.03 \pm 0.43$ & $8.91 \pm 0.20$ & 0.772 \\
\hline
\end{tabular}

Data are presented as mean \pm standard error, MTHFR: Methylenetetrahydrofolate reductase, T2DM: Type 2 diabetes mellitus, HbA1c: Glycosylated hemoglobin,

$\mathrm{n}$ : Number of individuals

according to AA versus AC+CC genotypes revealed two-fold increased risk for the diabetes and its complications. A previous study conducted in the Tunisian population has reported that the MTHFR A1298C was significantly associated with type 2 diabetes [23]. Another study suggested that MTHFR A1298C polymorphism is a risk factor for T2DM in Egyptian population [24], while other studies did not find any association with diabetes in Taiwanese and Moroccan population [25,26].

Regarding diabetic complications, few studies have found the association of this polymorphism with coronary heart disease in Chinese population [27], ischemic stroke in Tunisian population [28], and retinopathy in Egyptian population [29]. A previous study conducted in a south Indian population has reported that the MTHFR A1298C gene polymorphism might lead to an increased risk for the occurrence of acute myocardial infarction [30]. In contrary, the MTHFR A1298C variant was not associated with the development of type 2 diabetic nephropathy in Chinese population [31] and in Caucasians [32]. The occurrence of the mutant allele frequency varies in different population. This might be due to ethnic variations, geographical background, and interindividual differences of the studied population. The prevalence of the MTHFR A1298C gene polymorphism in healthy controls is shown in Table 4.

Association of MTHFR gene polymorphism, DNA damage, and TAS When the genotypes (AA, AC, and CC) of MTHFR gene 1298 were related individually to DNA damage and TAS, a statistically significant difference between the diabetic patients (with and without complications) and controls was observed. We found an association between the MTHFR 1298 genotypes and DNA damage in both the diabetic patients with and without complications. This shows that MTHFR A1298C genotypes had an effect on DNA damage in individuals with T2DM. We did not find any association between the MTHFR 1298 genotypes and the levels of TAS among the study subjects. However, TAS was found to be decreased in T2DM patients when compared to controls irrespective of the genotypes. This may be due to hyperglycemia, which has a direct 
Table 4: Prevalence of the MTHFR A1298C gene polymorphism in healthy controls

\begin{tabular}{|c|c|c|c|c|}
\hline \multirow[t]{2}{*}{ Country } & \multirow[t]{2}{*}{ Ethnic population } & \multirow{2}{*}{$\begin{array}{l}\text { No. of subjects } \\
\text { (N) }\end{array}$} & \multirow{2}{*}{$\begin{array}{l}\text { Mutant (C) allele } \\
\text { Frequency }\end{array}$} & \multirow[t]{2}{*}{ References } \\
\hline & & & & \\
\hline India & South Indian & 100 & 0.41 & (Present study) \\
\hline Tunisia & Tunisian & 200 & 0.03 & [23] \\
\hline Japan & Japanese & 243 & 0.20 & [37] \\
\hline Brasil & Brasilian & 356 & 0.26 & [38] \\
\hline UAE & Emirati & 169 & 0.61 & [36] \\
\hline Turkey & Turkish & 112 & 0.40 & [39] \\
\hline Egypt & Egyptian & 310 & 0.32 & [29] \\
\hline China & Chinese & 680 & 0.19 & [15] \\
\hline Egypt & Egyptian & 60 & 0.22 & [24] \\
\hline Pakistan & Pakistani & 872 & 0.55 & [7] \\
\hline Australia & Australian & 386 & 0.35 & [40] \\
\hline Taiwan & Taiwanese & 62 & 0.28 & [25] \\
\hline UK & British & 759 & 0.32 & [41] \\
\hline Tunisia & Tunisian & 400 & 0.20 & [42] \\
\hline Italy & Italian & 261 & 0.30 & [43] \\
\hline
\end{tabular}

effect on TAS in T2DM patients. The previous finding also suggests that hyperglycemia contributes to increased oxidative stress and decreased TAS, which would lead to further increase in DNA damage in patients with diabetes and its complications [33].

In the present study, the level of DNA damage was found to be higher in patients with complications when compared to patients without complications. Evidence suggests that patients with diabetic neuropathy have increased oxidative DNA damage than patients with diabetes [34]. Another finding suggests that individuals with diabetes have been shown to have increased oxidative DNA damage and decreased antioxidative defense relative to the overproduction of free radicals [35].

Association of MTHFR 1298 genotypes versus clinical and biochemical parameters in T2DM

The present study shows that the clinical and biochemical variables have no association with the occurrence of genotypes in individuals with diabetes. Similarly, previous studies have found no significant associations between lipid/glucose metabolic indexes with MTHFR 1298 genotypes among T2DM patients [24,25]. Another study also has reported that BMI, hypertension, family history, $\mathrm{HbA} 1 \mathrm{c}$, total cholesterol, and fasting blood glucose of the diabetic patients segregated according to the MTHFR 1298 genotypes genotypes were similar except triglyceride levels [36].

\section{CONCLUSION}

The MTHFR A1298C gene polymorphism is considered as a risk factor for the development of diabetes and its complications among south Indians. Therefore, increased DNA damage and decreased TAS along with the occurrence of the MTHFR 1298 mutant genotype in an individual with diabetes may be at an increased risk for the development of chronic complications. Future researchers may focus on the investigation of gene-nutrient interactions and epigenetic interactions for better understanding of the role of folate metabolism genes in the risk of diabetes and its complications among the south Indian population.

\section{CONFLICT OF INTEREST}

The authors declare that there were no conflicts of interest for financial interests associated with this manuscript.

\section{ACKNOWLEDGMENT}

Financial assistance received from University Grants CommissionMajor Research Project, New Delhi \{F. No. - 43 - 577/2014 (SR)\}, to Principal Investigator Dr. W. Isabel is greatly acknowledged.

\section{REFERENCES}

1. Levitt NS, Bradshaw D, Zwarenstein MF, Bawa AA, Maphumolo S. Audit of public sector primary diabetes care in Cape Town, South Africa: High prevalence of complications, uncontrolled hyperglycaemia, and hypertension. Diabet Med 1997;14:1073-7.

2. Adak S, Sengupta S, Chowdhury S, Bhattacharyya M. Co-existence of risk and protective haplotypes of calpain 10 gene to Type 2 diabetes in the eastern Indian population. Diab Vasc Dis Res 2010;7:63-8.

3. Wallace JI. Management of diabetes in elderly. Clin Diabetes 2004;17:1.

4. van Tilburg J, van Haeften TW, Pearson P, Wijmenga C. Defining the genetic contribution of Type 2 diabetes mellitus. J Med Genet 2001;38:569-78.

5. Barbosa PR, Stabler SP, Machado AL, Braga RC, Hirata RD, Hirata MH, et al. Association between decreased vitamin levels and MTHFR, MTR and MTRR gene polymorphisms as determinants for elevated total homocysteine concentrations in pregnant women. Eur J Clin Nutr 2008;62:1010-21.

6. Sukla KK, Raman R. Association of MTHFR and RFC1 gene polymorphism with hyperhomocysteinemia and its modulation by vitamin B12 and folic acid in an Indian population. Eur J Clin Nutr 2012;66:111-8

7. Yakub M, Moti N, Parveen S, Chaudhry B, Azam I, Iqbal MP, et al. Polymorphisms in MTHFR, MS and CBS genes and homocysteine levels in a Pakistani population. PLoS One 2012;7:e33222.

8. Frosst P, Blom HJ, Milos R, Goyette P, Sheppard CA, Matthews RG, et al. A candidate genetic risk factor for vascular disease: A common mutation in methylenetetrahydrofolate reductase. Nat Genet 1995;10:111-3.

9. Weisberg I, Tran P, Christensen B, Sibani S, Rozen R. A second genetic polymorphism in methylenetetrahydrofolate reductase (MTHFR) associated with decreased enzyme activity. Mol Genet Metab 1998;64:169-72.

10. Friso S, Choi SW, Girelli D, Mason JB, Dolnikowski GG, Bagley PJ, et al. A common mutation in the 5,10-methylenetetrahydrofolate reductase gene affects genomic DNA methylation through an interaction with folate status. Proc Natl Acad Sci U S A 2002;99:5606-11.

11. Finkelstein JD. Pathways and regulation of homocysteine metabolism in mammals. Semin Thromb Hemost 2000;26:219-25.

12. Yi P, Melnyk S, Pogribna M, Pogribny IP, Hine RJ, James SJ, et al. Increase in plasma homocysteine associated with parallel increases in plasma S-adenosylhomocysteine and lymphocyte DNA hypomethylation. J Biol Chem 2000;275:29318-23.

13. Crott J, Fenech M. Preliminary study of the genotoxic potential of homocysteine in human lymphocytes in vitro. Mutagenesis 2001;16:213-7.

14. Dong C, Yoon W, Goldschmidt-Clermont PJ. DNA methylation and atherosclerosis. J Nutr 2002;132:2406S-9S.

15. Wang $\mathrm{H}, \mathrm{Hu} \mathrm{C}$, Xiao $\mathrm{SH}$, Wan B. Association of tagging SNPs in the MTHFR gene with risk of Type 2 diabetes mellitus and serum homocysteine levels in a Chinese population. Dis Markers 2014;2014:725731. 
16. Benzie IF, Strain JJ. The ferric reducing ability of plasma (FRAP) as a measure of "antioxidant power": The FRAP assay. Anal Biochem 1996;239:70-6.

17. Tice RR, Agurell E, Anderson D, Burlinson B, Hartmann A, Kobayashi $\mathrm{H}$, et al. Single cell gel/comet assay: Guidelines for in vitro and in vivo genetic toxicology testing. Environ Mol Mutagen 2000;35:206-21.

18. Singh NP, McCoy MT, Tice RR, Schneider EL. A simple technique for quantitation of low levels of DNA damage in individual cells. Exp Cell Res 1988;175:184-91.

19. Iranpur MV, Esmailizadeh AK, Horriat R, Asadi KE, Shiran B, Sorkheh K, et al. Rapid extraction of high quality DNA from whole blood stored at $4^{\circ} \mathrm{C}$ for long period. Iran: Department of Animal Science, Faculty of Agriculture, Shahrekord University, Shahrekord, Protocol Online; 2002

20. Friedman G, Goldschmidt N, Friedlander $Y$, Ben-Yehuda A, Selhub J, Babaey S, et al. A common mutation A1298C in human methylenetetrahydrofolate reductase gene: Association with plasma total homocysteine and folate concentrations. J Nutr 1999;129:1656-61.

21. Hussain M, Naqvi SB, Khan MA, Rizvi M, Alam S, Abbas A, et al. Direct cost of treatment of diabetes mellitus Type 2 in Pakistan. Int J Pharm Pharm Sci 2014;6:261-4.

22. Andayani TM, Ibrahim MI, Asdie AH. The association of diabetesrelated factor and quality of life in Type 2 diabetes mellitus. Int J Pharm Pharm Sci 2010;2:139-45.

23. Fekih-Mrissa N, Mrad M, Ibrahim H, Akremi I, Sayeh A, Jaidane A, et al. Methylenetetrahydrofolate reductase (MTHFR) (C677T and A1298C) polymorphisms and vascular complications in patients with Type 2 diabetes. Can J Diabetes 2017;41:366-71.

24. AbdRaboh NR, Badr S, Ali S. Prevalence of methylenetetrahydrofolate reductase C677T and A1298C polymorphisms in Egyptian patients with Type 2 diabetes mellitus. Egypt J Med Hum Genet 2013;14:87-93.

25. Chang YH, Fu WM, Wu YH, Yeh CJ, Huang CN, Shiau MY, et al. Prevalence of methylenetetrahydrofolate reductase C677T and A1298C polymorphisms in Taiwanese patients with Type 2 diabetic mellitus. Clin Biochem 2011;44:1370-4

26. Benrahma H, Abidi O, Melouk L, Ajjemami M, Rouba H, Chadli A, et al. Association of the C677T polymorphism in the human methylenetetrahydrofolate reductase (MTHFR) gene with the genetic predisposition for Type 2 diabetes mellitus in a Moroccan population. Genet Test Mol Biomarkers 2012;16:383-7.

27. Sun J, Xu Y, Xue J, Zhu Y, Lu H. Methylenetetrahydrofolate reductase polymorphism associated with susceptibility to coronary heart disease in Chinese Type 2 diabetic patients. Mol Cell Endocrinol 2005;229:95-101.

28. Fekih-Mrissa N, Mrad M, Klai S, Mansour M, Nsiri B, Gritli N, et al. Methylenetetrahydrofolate reductase (C677T and A1298C) polymorphisms, hyperhomocysteinemia, and ischemic stroke in Tunisian patients. J Stroke Cerebrovasc Dis 2013;22:465-9.

29. Settin A, El-Baz R, Ismaeel A, Tolba W, Allah WA. Association of ACE and MTHFR genetic polymorphisms with Type 2 diabetes mellitus: Susceptibility and complications. J Renin Angiotensin Aldosterone Sys 2015; $16: 838-43$
30. Angeline T, Jeyaraj N, Tsongalis GJ. MTHFR gene polymorphisms, $\mathrm{B}$-vitamins and hyperhomocystinemia in young and middle-aged acute myocardial infarction patients. Exp Mol Pathol 2007;82:227-33.

31. Wang D, Bai L, Zhai Q, Li Y, Cao M, Hai J, et al. Association of MTHFR C677T and A1298C polymorphisms with the development of Type 2 diabetic nephropathy and their interaction with environmental factors. Int J Clin Exp Pathol 2017;10:3778-85.

32. Moczulski D, Fojcik H, Zukowska-Szczechowska E, Szydlowska I, Grzeszczak W. Effects of the C677T and A1298C polymorphisms of the MTHFR gene on the genetic predisposition for diabetic nephropathy. Nephrol Dial Transplant 2003;18:1535-40.

33. Nithya K, Isabel W, Angeline T, Priscilla AS, Asirvatham AJ. Assessment of DNA strand breaks and total antioxidant status in Type 2 diabetic patients with and without complications- A case-control study. Asian J Pharm Clin Res 2017;10:430-4

34. Majsterek I, Merecz A, Sliwinska A, Kosmalski M, Kasznicki J, Drzewoski J. Role of oxidative DNA damage in pathogenesis of diabetic neuropathy. World academy of science, engineering and technology. Int J Med Health Biomed Bioeng Pharm Eng 2012;6:494-501.

35. Rytter E, Vessby B, Asgård R, Johansson C, Sjödin A, AbramssonZetterberg L, et al. Glycaemic status in relation to oxidative stress and inflammation in well-controlled Type 2 diabetes subjects. Br J Nutr 2009;101:1423-6.

36. El Hajj Chehadeh SW, Jelinek HF, Al Mahmeed WA, Tay GK, Odama UO, Elghazali GE, et al. Relationship between MTHFR C677T and $\mathrm{A} 1298 \mathrm{C}$ gene polymorphisms and complications of Type 2 diabetes mellitus in an Emirati population. Meta Gene 2016;9:70-5.

37. Matsuo K, Suzuki R, Hamajima N, Ogura M, Kagami Y, Taji H, et al. Association between polymorphisms of folate-and methioninemetabolizing enzymes and susceptibility to malignant lymphoma. Blood 2001;97:3205-9.

38. Peres NP, Galbiatti-Dias AL, Castanhole-Nunes MM, da Silva RF, Pavarino ÉC, Goloni-Bertollo EM, et al. Polymorphisms of folate metabolism genes in patients with Cirrhosis and hepatocellular carcinoma. World J Hepatol 2016;8:1234-43.

39. Tetik Vardarlı A, Zengi A, Bozok Çetintaş V, Karadeniz M, Tamsel S, Küçükaslan AȘ, et al. An association study between gene polymorphisms of folic acid metabolism enzymes and biochemical and hormonal parameters in acromegaly. Genet Test Mol Biomarkers 2015; 19:431-8.

40. Fowdar JY, Lason MV, Szvetko AL, Lea RA, Griffiths LR. Investigation of homocysteine-pathway-related variants in essential hypertension. Int J Hypertens 2012;2012:190923.

41. Lightfoot TJ, Johnston WT, Painter D, Simpson J, Roman E, Skibola CF, et al. Genetic variation in the folate metabolic pathway and risk of childhood leukemia. Blood 2010;115:3923-9.

42. Mtiraoui N, Ezzidi I, Chaieb M, Marmouche H, Aouni Z, Chaieb A, et al. MTHFR C677T and A1298C gene polymorphisms and hyperhomocysteinemia as risk factors of diabetic nephropathy in type 2 diabetes patients. Diabetes Res Clin Pract 2007;75:99-106.

43. Scala I, Granese B, Sellitto M, Salomè S, Sammartino A, Pepe A, et al. Analysis of seven maternal polymorphisms of genes involved in homocysteine/folate metabolism and risk of down syndrome offspring. Genet Med 2006;8:409-16. 